\title{
POTENSI LACTOBACILLUS PLANTARUM SEBAGAI INTERVENSI PENATALAKSANAAN KANKER KOLOREKTAL BERBASIS MODIFIKASI MIKROBIOTA USUS
}

\author{
1| Anak Agung Bagus Putra Indrakusuma , 2| I Gede Krisna Arim Sadeva, 3| Putri Ayu Wulandari, \\ 4| I Gede Wikania Wira Wiguna , 5| Ni Putu Sri Indrani Remitha, 6| I Gusti Ayu Stiti Sadvika, \\ 7| I Gede Putu Supadmanaba, 8| Desak Made Wihandani \\ Email : indrakusuma@student.unud.ac.id
}

\begin{abstract}
Colorectal cancer is a cancer of the colon including the colon and rectum with symptoms such as blood in the stool, anemia, and abdominal pain. This is the third most common cancer worldwide and causes 30.017 cases in Indonesia on 2019. Current treatment of colorectal cancer includes the administration of chemotherapy, surgery, and radiotherapy. However, they are considerably expensive and have many side effects. Lactobacillus plantarum (L. plantarum) is known to have an anticancer effect by influencing carcinogenesis in cell proliferation, apoptosis, and stimulates anticancer immunity. This literature review aims to examine the potential of L. plantarum as an intervention in the management of colorectal cancer based on the modification of the gut microbiota. The writing method used is literature study by examining library sources from five research engines, namely Google Scholar, Pubmed, Plos ONE, Nature, and Sciencedirect. After going through the screening, 79 relevant sources were obtained which were then processed and compiled systematically. L. plantarum suppresses proliferation by inhibiting G1 phase in the cell cycle and targetting ErbB2 and ErbB3. In addition, L. plantarum induces cell death (apoptosis) by activating Bcl-2. These bacteria also stimulate Th1 and inhibit Th2 immune responses.
\end{abstract}

ARTICLE INFO

\author{
Keywords: \\ Colorectal cancer; Gut microbiota; \\ Lactobacillus plantarum
}

DOI:

$\underline{10.24252 / \text { kesehatan.v13i2. } 17044}$

\section{Pendahuluan}

Kanker kolorektal ialah kanker pada usus besar meliputi kolon serta rektum (1). Adapun gejala yang ditimbulkan berupa abnormalitas defekasi, perdarahan feses, anemia, berat badan menurun, dan nyeri pada bagian abdomen (2). Menurut laporan Global Burden of Cancer Study (GLOBOCAN) pada tahun 2018, kanker kolorektal menduduki peringkat ketiga kanker dengan penderita terbanyak dan mudah ditemukan secara global ( 2 juta kasus baru dan 1 juta kematian) (3) (4). Di Indonesia sendiri, insiden kanker kolorektal mencapai 8,6\% (30.017 kasus) dan menempati peringkat keempat dari segala jenis kanker (5).

Penatalaksanaan kanker kolorektal saat ini meliputi pemberian kemoterapi sistemik, radioterapi, dan pembedahan (6). Akan tetapi, penanganan saat ini dinilai mahal dan menimbulkan efek samping. Tindakan operasi diketahui tidak dapat mengangkat sel kanker seutuhnya. Sementara itu, radioterapi dan pemberian obat anti-kanker dapat memicu efek samping terhadap sel normal tubuh (7) (8) (9) (10).

Berbagai modalitas baru dikembangkan sehingga mampu mencapai efikasi dan minim efek samping. Hal ini penting dilakukan untuk mendapatkan pembaharuan terapi dan penatalaksanaan kanker kolorektal. Salah satu modalitas tersebut adalah mikrobiota usus (11). Pengkonsumsian bakteri yang bermanfaat terhadap tubuh seperti probiotik dapat memodulasi mikroorganisme pada sistem gastrointestinal sehingga memiliki kaitan yang erat dengan kolorektal (12).

Lactobacillus plantarum merupakan probiotik potensial sebagai penatalaksanaan kanker kolorektal (13). L.plantarum merupakan golongan lactic acid bacteria (LAB) yang dapat dicerna dalam produk susu fermentasi atau sebagai suplemen (14). Bakteri ini memberikan efek yang menguntungkan untuk inang dengan meningkatkan keseimbangan mikroba usus (12).

L. plantarum adalah strain bakteri probiotik serbaguna yang biasanya ditemukan di berbagai produk makanan fermentasi (15). Bakteri ini banyak digunakan dalam fermentasi industri dan pemrosesan makanan mentah dan diakui aman secara umum dengan terpenuhinya status

\footnotetext{
1,2,3,4,5,6 Program Studi Sarjana Kedokteran dan Profesi Dokter Fakultas Kedokteran Universitas Udayana, 
Anak Agung Bagus Putra Indrakusuma, I Gede Krisna Arim Sadeva, Putri Ayu Wulandari, I Gede Wikania Wira Wiguna, Ni Putu Sri Indrani Remitha, I Gusti Ayu Stiti Sadvika, I Gede Putu Supadmanaba, Desak Made Wihandani: Potensi lactobacillus plantarum sebagai intervensi penatalaksanaan kanker kolorektal berbasis modifikasi mikrobiota usus. Jurnal Kesehatan. Vol 13 (2) 2020

Qualified Presumption of Safety (QPS) $(16 ; 17)$. L. plantarum adalah salah satu mikrobiota usus yang menjadi modalitas tatalaksana kanker kolorektal modern. L. plantarum diketahui dapat menekan proses karsinogenesis pada beberapa penelitian melalui beragam mekanisme (18) (19) (20) (21).

Berdasarkan hal tersebut, dapat diketahui bahwa potensi L. plantarum sebagai penatalaksanaan kanker kolorektal sangat besar. Oleh sebab itu, penulis tertarik mengangkat topik ini sehingga mendapatkan pemahaman yang lebih mendalam. Literature review ini bertujuan untuk mengkaji potensi L. plantarum sebagai intervensi penanganan kanker kolorektal berbasis mikrobiota usus sehingga dapat membuka peluang penelitian lanjutan.

\section{Tinjauan Pustaka}

\section{Lactobacillus plantarum}

Lactobacillus plantarum (L. plantarum) merupakan kelompok bakteri gram positif, nonmotil, tidak berspora, microaerophilic, dan mesophilic yang berkembang pada suhu $10-15^{\circ} \mathrm{C}$ (maksimal suhu $45^{\circ} \mathrm{C}$ ). Bakteri ini memiliki sel berbentuk batang lurus dengan ujung membulat, 0.9-1.2 $\times 3.0-8.0 \mu \mathrm{m}$, individual, berpasangan, atau dalam rantai pendek (22). Strain dari $L$. plantarum berpotensi berguna dalam bioteknologi, bioremediasi, produk farmasi, dan dalam pembuatan bakteriosin. Tidak ditemukan strain yang memiliki gen resistensi antibiotik atau faktor virulensi pada bakteri ini (23).

L. plantarum memengaruhi proses karsinogenesis melalui tiga mekanisme, yaitu proliferasi, apoptosis, dan imunoterapi pada kanker kolorektal. Proliferasi sel dapat dihambat oleh bakteri tersebut dengan menghentikan siklus sel pada fase G1 (21). L. plantarum juga menginduksi kematian sel dengan mediasi Bcl-2 (18) (20). Selain itu, bakteri ini mampu memengaruhi sistem imun khususnya host defense system dalam melawan aktivitas sel kanker (19).

\section{Patogenesis Kanker Kolorektal dan Kaitannya dengan Mikrobiota Usus}

Kanker kolorektal merupakan salah satu kanker yang memiliki jalur patogenesis kompleks, dipengaruhi oleh mikrosatelit atau instabilitas kromosom (24). Kanker kolorektal berkembang dari sel epitel mukosa kolon normal melalui akumulasi progresif dari perubahan genetik, seperti mutasi pada adenomatous polyposis coli (APC) selama tahap awal dan mutasi pada onkogen homolog rat sarcoma (RAS) dan tumor protein 53 (TP53) saat tahap lanjutan (25).

Mengacu terhadap model genetiknya, terdapat setidaknya tiga rute evolusioner patologi klinik yang berbeda untuk kanker kolorektal sporadis. Pertama, jalur tradisional (traditional pathway) yang dimulai dari mukosa normal melalui tubular adenoma (dengan mutasi APC) dan menghasilkan kanker kolorektal khas di bagian distal usus besar (dengan mutasi TP53 dan ketidakstabilan kromosom). Kedua, jalur bergerigi (serrated pathway) yang dimulai dari mukosa normal melalui adenoma bergerigi dengan mutasi $v$-raf murine sarcoma viral oncogene homolog B1 (BRAF) dan CpG island methylator phenotype (CIMP) dan mengakibatkan kanker di bagian proksimal usus besar dengan prognosis yang baik, kehilangan mutL homolog 1 (MLH1) dan ketidakstabilan mikrosatelit. Ketiga, jalur alternatif (alternative pathway) dimulai dari mukosa normal melalui villous, sebagian adenoma bergerigi dengan KRAS, BRAF, serta mutasi APC dan CIMP dan menyebabkan kanker kolon dengan prognosis buruk yang ditandai dengan CIMP pada Gambar 1 (26) (27).

Beberapa penelitian menunjukkan spesies bakteri tertentu diketahui memiliki keterkaitan terhadap patogenesis kanker kolorektal khususnya mikrobiota usus, seperti $S$. bovis, Fusobacterium nucleatum, Escherichia coli, Bacteroides fragilis, Enterococcus faecalis dan Helicobacter pylori ( 28) (25) (29) (27) (30) (31) (32) (33) (24) (34) (35). Streptococcus bovis/gallolyticus mampu berkoloni dan tumbuh pada jaringan kolorektal melalui ikatan kolagen dan histon-protein A dengan kolagen I, IV, fibronectin, serta fibrinogen pada jaringan kolon. Aktivitas mikrobiota tersebut dapat menyebabkan respon inflamasi yang parah dengan menginduksi sitokin angiogenik dan inflamasi di jaringan kolorektal serta dapat berujung pada 
perkembangan proliferasi kanker kolorektal (32).

Penelitian Sittipo et al menunjukkan Bacteroides fragilis juga mengalami peningkatan pada sampel tinja penderita kanker kolorektal. B.fragilis mendegradasi protein E-cadherin dan mengaktivasi nuclear $\beta$-catenin signalling serta menginduksi ekspresi myc-oncogene (c-Myc) dan proliferasi sel (31). Menurut penelitian Shang et al, Fusobacterium nucleatum juga diyakini berperan dalam patogenesis kanker kolorektal. F. nucleatum menempel pada sel epitel kolon melalui ikatan Fusobacterium adhesin $A$ (FadA). FadA berikatan dengan E-cadherin yang mengaktivasi $\beta$-catenin signaling serta mengatur respon onkogen dan inflamasi. Fibroblast activation protein 2 (Fap2) dari F. nucleatum mampu menstimulasi ekspansi kanker kolorektal dengan menghambat aktivitas sel imun antitumor melalui T-cell immunoglobulin and immunoreceptor tyrosine-based inhibitory motif (ITIM) (30).

Sementara itu, mikrobiota lain seperti Enterococcus faecalis dapat menghasilkan reactive oxygen and nitrogen species (RONS) yang berujung pada pemecahan DNA, mutasi titik, dan ketidakstabilan kromosom. Hal ini dapat berperan dalam transformasi onkogen pada kolon (29). Bakteri vacuolating cytotoxin A (VacA) dan cytotoxin-associated gene A (CagA) mampu dikodekan oleh Helicobacter pylori dan menginduksi aktivasi inflamasi dengan mengekspresikan persinyalan tumor necroting factor- $\alpha$ (TNF- $\alpha$ ) (34). Pada akhirnya, aktivasi NF-kB dan Akt pathways menginduksi aktivasi $\beta$-catenin dan progresi kanker kolorektal melalui jalur ekstrinsik. Escherichia coli yang diisolasi dari penderita kanker kolorektal berperan dalam sintesis colibactin, jenis genotoxin lain yang mengganggu siklus sel dan memicu proliferasi sel epitel melalui kerusakan DNA, pertumbuhan tumor, mutasi, dan ketidakstabilan genom (35).

Secara umum mikrobiota usus berperan dalam karsinogenesis dengan memproduksi metabolit sekunder seperti perantara oksigen reaktif yang menyebabkan kerusakan DNA atau efek langsung pada transformasi sel melalui produksi genotoxin (33). Inflamasi yang disebabkan oleh mikrobiota berperan dalam perkembangan kanker kolorektal. Jalur dengan peran sentral dalam sel-sel myeloid dan limfoid, seperti yang terkait dengan signal transducer and activator of transcription 3 (STAT3) serta NF-kB, juga aktif dalam perubahan epitel usus dan memicu perkembangan tumor (25)

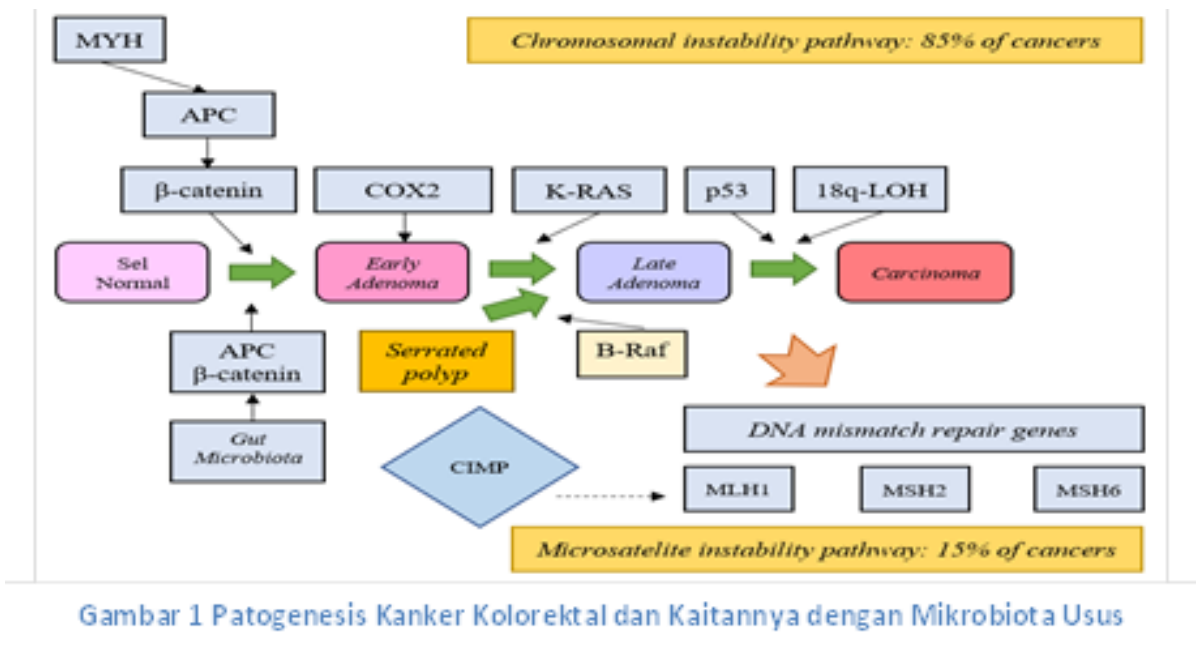

\section{Metodologi Penelitian}

Adapun dalam penulisan digunakan metode studi literatur. Database ilmiah berbasis online pada lima research engine yaitu Google Scholar, Pubmed, Plos ONE, Nature, dan Sciencedirect. Kata kunci yang digunakan adalah "Lactobacillus plantarum" dan "colorectal cancer". Setelah proses studi literatur kemudian dilakukan skrining dengan mempertimbangkan relevansi data dan diperoleh 79 sumber pustaka valid. Kemudian, data-data tersebut diolah dan disusun secara sistematis sesuai dengan topik masalah yang dibahas. 
Anak Agung Bagus Putra Indrakusuma, I Gede Krisna Arim Sadeva, Putri Ayu Wulandari, I Gede Wikania Wira Wiguna, Ni Putu Sri Indrani Remitha, I Gusti Ayu Stiti Sadvika, I Gede Putu Supadmanaba, Desak Made Wihandani: Potensi lactobacillus plantarum sebagai intervensi penatalaksanaan kanker kolorektal berbasis modifikasi mikrobiota usus. Jurnal Kesehatan. Vol 13 (2) 2020

\section{Hasil Dan Pembahasan}

\section{Efek Antiproliferasi oleh L. plantarum pada Kanker Kolorektal}

Probiotik spesifik memberikan efek anti-proliferasi melalui tindakan sinergis antara adhesi sel kanker kolon dan produksi asam butirat dan propionat (khususnya) dan asam lemak rantai pendek lainnya (36). Sel probiotik tersebut juga dapat bertindak secara kompetitif dan menghambat adhesi dan invasi patogen pada usus dan menstimulasi host immune response (37).

L. plantarum menghambat proliferasi dengan memengaruhi siklus sel melalui penghentian pada fase G1. Transisi dari fase G1 menuju fase S pada siklus sel tergantung pada aktivitas cyclin $E$ cyclin dependent kinase (CDK), sedangkan progresi melalui fase S dikendalikan oleh cyclin $A$ CDK2 (21). Baik gen cyclin $E$ maupun cyclin $A$ diturunkan aktivitasnya setelah manajemen sel dengan media terkondisi yang menunjukkan kemungkinan tautan terhadap observasi penghentian siklus sel (37). Adapun target reseptor terkait ialah ErbB2 dan ErbB3 yang menurunkan mekanisme penginduksian molekul E2F dan cyclin D1 pada Gambar 5A.

Penelitian Hiraishi et al menginkubasi cell line kanker kolorektal (HT29 dan Caco2) dengan penambahan ekstrak LP06CC2 (38). Adapun penelitiannya terbagi menjadi lima kelompok dosis yaitu kontrol, LP06CC2 1\%, LP06CC2 5\%, LP06CC2 10\%, dan LP06CC2 20\%. Ekstrak LP06CC2 dalam tiga kelompok waktu $(24,48$, dan 72 jam) menunjukkan efek antiproliferasi melalui pengukuran kepadatan sel dengan optical density $450 \mathrm{~nm}$. Adapun efek antiproliferasi pada cell line HT29 di masing-masing kelompok, yakni kelompok kontrol, LP06CC2 1\%, LP06CC2 5\%, LP06CC2 10\%, dan LP06CC2 20\% yang terdeteksi pada 24 jam dan 48 jam tidak menunjukkan perbedaan yang bermakna. Hasil penelitian menunjukkan cell line HT29 terjadi penurunan proliferasi sel yang signifikan pada LP06CC2 72 jam jika dibandingkan dengan LP06CC2 24 jam dan LP06CC2 48 jam dalam lima kelompok dosis (Gambar 2A). Sementara itu, cell line Caco2 mengalami penurunan proliferasi sel yang signifikan pada LP06CC2 72 jam (Gambar 2B). LP06CC2 48 jam juga menunjukkan penurunan proliferasi sel yang cukup signifikan sedangkan LP06CC2 24 jam cenderung statis jika dibandingkan dengan kontrol. Adapun efek antiproliferasi pada masing-masing kelompok, yakni kelompok kontrol tidak menunjukkan hasil yang signifikan, LP06CC2 1\% menunjukkan penurunan yang signifikan pada 48 jam dan 72 jam, sedangkan kelompok LP06CC2 5\%, LP06CC2 10\%, dan LP06CC2 20\% menunjukkan penurunan yang bermakna pada 24, 48, dan 72 jam. Penelitian tersebut juga memperoleh aktivitas antiproliferasi yang potensial terjadi pada LP06CC2 1\% 72 jam pada cell line Caco2 (38).

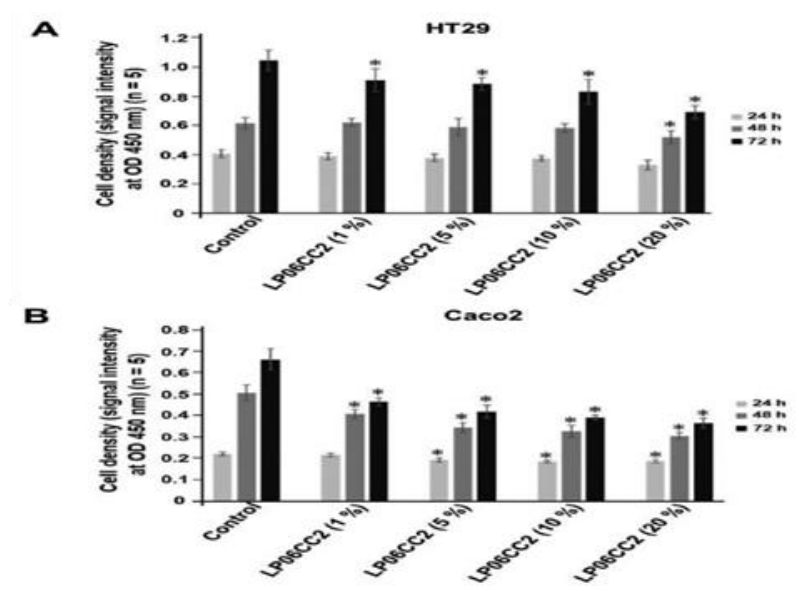

Gambar 2 Efek Antiproliferasi LP06CC2 pada Kanker Kolorektal HT29 dan Caco2 Cell Line (Hiraishi et al., 2019)

\section{Efek Apoptosis oleh L. plantarum pada Kanker Kolorektal}

L. plantarum mampu menginduksi apoptosis sel kanker dengan mensupresi protein antiapoptotik Bcl-2 yang diaktifkan melalui stres retikulum endoplasma dan jalur JNK / p38 
MAP kinase serta mengaktivasi protein proapoptotik Bax. Fungsi Bcl-2 dalam mitokondria telah diketahui memegang peran sentral dalam memicu apoptosis (18) (20). Bcl-2 dan $\mathrm{Bcl}_{\mathrm{XL}}$ berkontribusi untuk mempertahankan berbagai protein kanal pada membran luar mitokondria sehingga mencegah pelepasan sitokrom $C$ dan menyebabkan penekanan apoptosis, sedangkan faktor lain, seperti Bax, Bak, Bad, dan Bim menginduksi apoptosis melalui penurunan potensial membran mitokondria sehingga menyebabkan pelepasan sitokrom C (39) (40).

Di antara faktor-faktor pendukung apoptosis tersebut, Bim memiliki tiga isoform yaitu BimEL, BimL, dan BimS. Ekspresi tingkat BimL dan BimS meningkat sejalan dengan penginduksian apoptosis (41). PERK1, salah satu reseptor yang mengenali stres retikulum endoplasma, memfosforilasi eIF2 $\alpha$, serta meningkatkan ekspresi faktor transkripsi ATF4 dan CHOP (42).

Protein transmembran IRE1 $\alpha$ diaktifkan oleh akumulasi protein di retikulum endoplasma dan menstimulasi JNK / p38 MAPK, kemudian menginduksi apoptosis (43). Bcl-2 dan Bim merupakan substrat yang menginduksi apoptosis melalui jalur JNK, yang masing-masing dihambat dan diaktifkan oleh fosforilasi JNK (44). p38 MAPK memfosforilasi dan mengaktifkan faktor transkripsi CHOP (marker stres retikulum endoplasma) serta menyebabkan perubahan ekspresi gen yang mendukung apoptosis, termasuk meningkatkan ekspresi Bim dan mengurangi ekspresi Bcl-2 pada Gambar 5B (45).

Evaluasi efek apoptosis pada penelitian Hiraishi et al dilakukan secara in vitro menggunakan ekstrak LP06CC2 Caco2 cell line dalam tiga kelompok dosis yaitu kontrol, 10\%, dan 20\%. Sel yang mengalami apoptosis diukur dengan menggunakan TUNEL-staining assay dan menunjukkan hasil positif pada sel kanker yang diberikan ekstrak LP06CC2. Titik hijau merepresentasikan banyaknya sel yang mengalami apoptosis meningkat sejalan dengan peningkatan dosis LP06CC2 (Gambar 3A). LP06CC2 20\% menginduksi apoptosis terbanyak pada sel (Gambar 3B). Hasil serupa juga ditunjukkan pada pengukuran dengan menggunakan $V$ FITC/PI double-staining assay (Gambar 3C). Setiap kuadran menggambarkan sel yang berbeda, Q1 (sel nekrotik dan debrotik), Q2 (sel apoptosis akhir), Q3 (sel apoptosis awal), dan Q4 (sel normal). Total sel apoptosis baik awal maupun akhir kemudian dihitung rasionya (Gambar 3D). LP06CC2 20\% memiliki kemampuan terbaik dengan rasio apoptosis $\geq 20 \%$. Berdasarkan hasil penelitian tersebut, komponen pada ekstrak LP06CC2 dapat menyebabkan kematian sel dari aktivasi p53 secara independen (38).

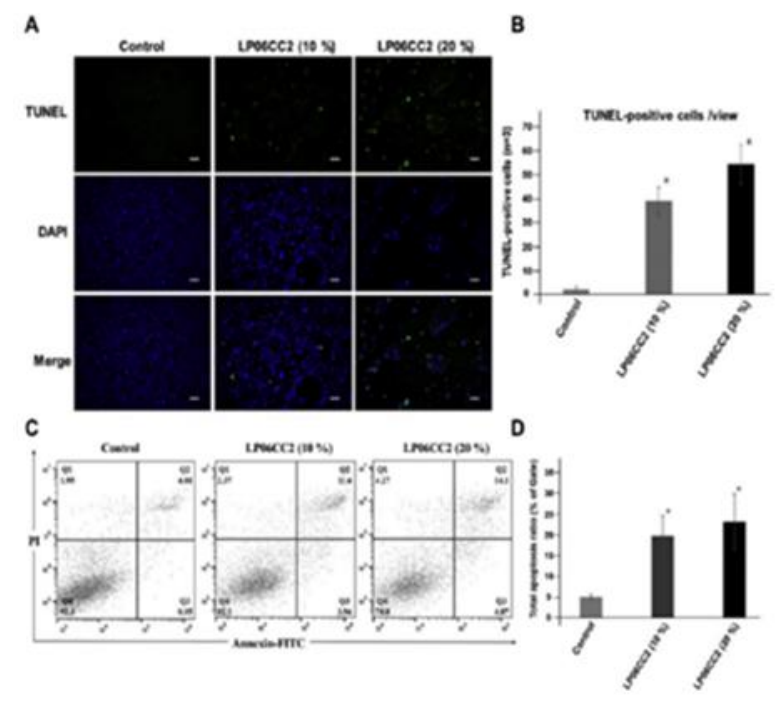

Gambar 3 Efek Apoptosis LP06CC2 pada Kanker Kolorektal Caco2 Cell Line (38)

\section{Efek Imunoterapi oleh L. plantarum pada Kanker Kolorektal}

Selama pertumbuhan, L. plantarum dapat menghasilkan antioksidan yang kemampuannya hampir mirip dengan $100 \mathrm{mg}$ vitamin C (46). Antioksidan dalam jumlah tersebut diketahui 
Anak Agung Bagus Putra Indrakusuma, I Gede Krisna Arim Sadeva, Putri Ayu Wulandari, I Gede Wikania Wira Wiguna, Ni Putu Sri Indrani Remitha, I Gusti Ayu Stiti Sadvika, I Gede Putu Supadmanaba, Desak Made Wihandani: Potensi lactobacillus plantarum sebagai intervensi penatalaksanaan kanker kolorektal berbasis modifikasi mikrobiota usus. Jurnal Kesehatan. Vol 13 (2) 2020

dapat menghambat peroksidasi dan menstimulasi radikal bebas untuk mencegah pembentukan tumor. L.plantarum mampu menurunkan diameter volume dan jumlah total tumor secara keseluruhan melalui perubahan peroksidasi lipid dan aktivitas enzim antioksidan di usus besar dan di plasma (12).

L. plantarum, dengan serat tanaman bioaktif $\beta$-glucan, inulin, pektin, pati resisten, pasca operasi meningkatkan kadar anti-inflamasi sitokin IL-6 dan mencegah infeksi luka ringan terhadap sekresi feses setelah 72 jam. Dalam hal ini, formulasi sinbiotik tidak memiliki efek antiinflamasi yang dapat disebabkan oleh tidak adanya pembersihan usus. Administrasi L.plantarum juga meningkatkan kadar IgG yang bermanfaat untuk imunitas dan diedarkan dalam bentuk 4 sub tipe IgG1, IgG2, IgG3, dan IgG4 dalam plasma darah (47).

L. plantarum dapat diabsorpsi oleh sel $M$ dan secara langsung memengaruhi sel imunokompeten Peyer patch untuk merangsang respon imun pada usus. Probiotik tersebut juga dapat diangkut ke jaringan limfoid sistemik, seperti jaringan mesenterik kelenjar getah bening atau limpa dan memberikan efek imunomodulator secara tidak langsung. L.plantarum dapat menghambat karsinogenesis kolon dengan meningkatkan kadar IgA sekretori feses dalam model kanker kolon pada tikus Balb/c dengan memodulasi respon imun pada makrofag dan splenosit. Selain itu, administrasi dengan ukuran partikel kecil diketahui meningkatkan produksi sitokin, seperti IL-12 dan IFN- $\alpha$, dan untuk meningkatkan proliferasi sel Th1 (48; 19).

Makrofag terjadi dalam dua tahap polarisasi yang berbeda, yaitu M1 dan M2. M1 menunjukkan fenotip pro-inflamasi dan M2 yang memiliki fenotip anti-inflamasi. M1 ditandai dengan produksi sitokin pro-inflamasi yang tinggi dan induksi respon imun Th1 sedangkan M2 menghasilkan mediator anti-inflamasi dan menginduksi respon imun Th2 (49; 50). Peran makrofag dalam perkembangan tumor tersebut sangat kompleks dengan plastisitas fenotipik dinamis makrofag yang menentukan inisiasi, perkembangan, dan metastasis tumor. Bakteri probiotik dapat menginduksi sekresi dari pro-inflamasi yang berpotensi sebagai sitokin antitumor (TNF- $\alpha$, IL-1 $\beta$, IL-18, IL-23) di strain yang spesifik (51) (52) (53).

Secara umum, makrofag M1 mensekresikan TNF- $\alpha$ dengan tingkat yang lebih tinggi dibandingkan dengan makrofag M1 anti-inflamasi. TNF- $\alpha$ dikenal dengan sifat anti-tumornya, pada dosis tinggi TNF- $\alpha$ dapat menginduksi apoptosis sel tumor, tetapi dapat mempercepat perkembangan tumor melalui invasi tumor dan metastasis pada dosis rendah kronis. Konsentrasi TNF- $\alpha$ ini menentukan tingkat keparahan dari kanker kolorektal (54) (55). Tingkat IL-1 $\beta$ yang lebih tinggi dapat menginduksi myeloid-derived suppressor cells (MDSC) yang menunjukkan kemiripan fenotifik dengan makrofag M2 anti-inflamasi yang mampu menekan imunitas anti-tumor dan mengakibatkan pertumbuhan tumor. Peningkatan sekresi IL-18 mungkin relevan dengan aktivitas anti-tumor strain Lactobacilli spesifik pada model kanker kolorektal tikus (12) 56). IL-18 juga sangat penting untuk homeostasis sel epitel usus dan perbaikan mukosa, mendorong proliferasi dan diferensiasi sel epitel usus, memproduksi lendir sel goblet, dan mengekspresikan protein tight junction (57) (58)

Ketika makrofag aktif, beberapa faktor sel, seperti NO, TNF- $\alpha$, oksigen reaktif perantara, dan zat lainnya diperlukan untuk pelepasan host immune defense. NO memiliki peran utama dalam host immune system dan memiliki kemampuan antimikroba dan antitumor, memodulasi produksi sitokin, serta merangsang diferensiasi sel Th. L. plantarum menstimulasi sitokin Th1 dibandingkan sitokin Th2 dalam splenosit tikus. Probiotik tersebut menginduksi sekresi sitokin Th1 (TNF- $\alpha$, IL-12 p70) terlepas dari jenis mitogen, tetapi hal itu menurun pada produksi sitokin Th2 tergantung pada tipe mitogen (19).

Selain itu, rasio IL-12 terhadap IL-10 diketahui sesuai dengan peningkatan splenosit. IL-12 dan IL-10 adalah sitokin primer yang berperan menjembatani kesenjangan antara innate dan acquired immunity (59). IL-12 mengaktifkan sel T dan sel NK untuk berproliferasi dan mensekresi interferon (IFN) $-\gamma$ untuk melisiskan sel target, sedangkan IL-10 menurunkan fungsi-fungsi ini dan menstimulasi pematangan sel-B dan produksi antibodi ( $60 ; 21$ ). Rasio IL- 
12 / IL10 yang rendah adalah ciri khas dari beberapa jenis kanker pada manusia (19). Keseimbangan sel Th1 / Th2 sangat penting untuk menjaga homeostasis host immune system. $L$. plantarum juga meningkatkan pelepasan IL-6 dan IL-17A dengan cara yang bergantung pada tipe mitogen. Sel Th17 memediasi peradangan dan kerusakan jaringan, mengontrol kondisi peradangan manusia dan gejala penyakit autoimun dengan mengeluarkan IL-17, IL-6, dan GMCSF pada Gambar 5C (20).

Sitokin Th1 (p70, TNF- $\alpha$, IL-12) dan Th2 (IL-5, IL-4) berkaitan erat terhadap efek imunoterapi $L$. plantarum pada sel kanker (19). Studi menyatakan bahwa strain L. plantarum menyeimbangkan Th1 dan Th2 dalam respon imun. L. plantarum mampu menghambat ekspresi Th2 dan menginduksi ekspresi Th1 $(61 ; 62)$. Baik konsentrasi rendah maupun tinggi, nano-sized $L$. plantarum (nLp) mampu menginduksi sekresi TNF- $\alpha$, IL-12, dan p70 pada sel yang tidak mendapat administrasi serta splenosit yang mendapat administrasi dengan lipopolisakarida (LPS) dan concanavalin A (ConA) (Gambar 4A). Dosis tinggi nLp mampu menginduksi sekresi TNF- $\alpha$ sebesar 71,0 dan meningkatkan IL-12 p70 sebesar 4,8 dan 2,8. Pada splenosit yang tidak mendapat administrasi, hanya nLp dosis rendah yang diinduksi produksi IL-4. nLp dosis rendah secara signifikan mengurangi level IL-4 pada LPS yang diinduksi kontrol $(p<0,05)$, sedangkan nLp dosis tinggi dan rendah secara signifikan mengurangi tingkat IL-4 pada kontrol yang diobati dengan ConA ( $\mathrm{p}<0,01)$. nLp dosis tinggi dan rendah tidak memengaruhi produksi IL-5 pada splenosit yang tidak diobati maupun yang diobat dengan LPS, tetapi memberikan pengaruh pada splenosit yang diinduksi oleh ConA (Gambar 4B) (19).

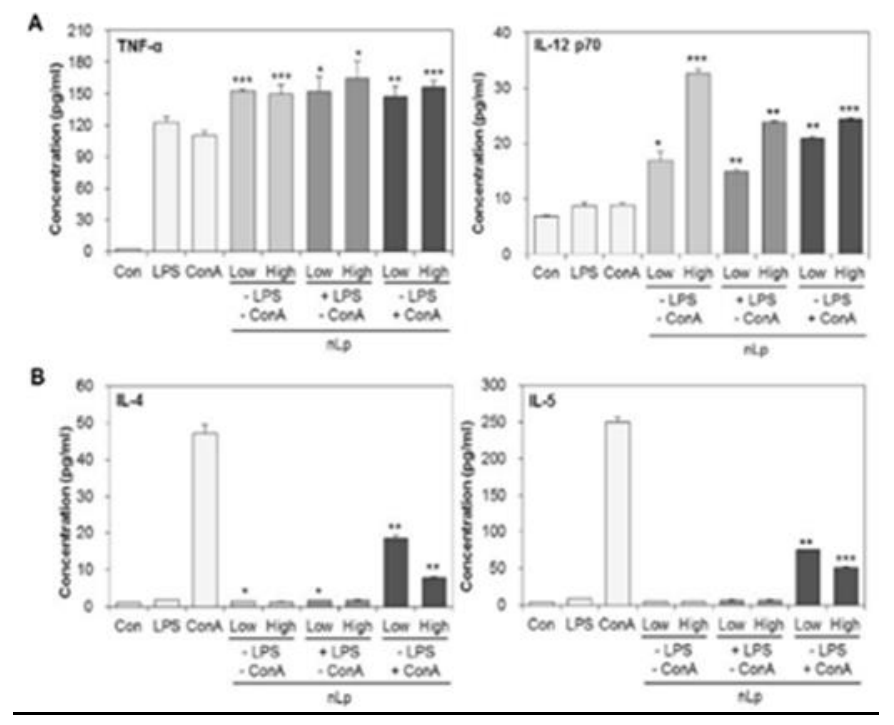

Gambar 4 Efek nano-sized L. plantarum (nLp) pada Produksi Sitokin Th1 dan Th2 (19)

Potensi L. plantarum sebagai Intervensi Preventif pada Kanker Kolorektal

Studi terkait mikrobiota usus termasuk L. plantarum menyatakan bahwa probiotik ini potensial digunakan sebagai penatalaksanaan atau pencegahan kanker kolorektal. Perkembangan polip dan perjalanan sel kanker menjadi malignant kemungkinan dapat dicegah dengan penggunaan mikrobiota usus dalam diet khususnya pada usia lanjut (13). Probiotik juga diketahui menghasilkan post-biotic metabolites (PM) bioaktif yang bermanfaat untuk mengobati penyakit pada usus, memelihara kesehatan usus, dan meningkatkan imunitas bawaan (63) (64) (65) (66). PM yang mengandung bakteriosin dibentuk oleh peptida kecil yang sebagian besar nonimunogenik dan biodegradable, sehingga aman untuk dikonsumsi dan tidak akan mencemari lingkungan (67). 


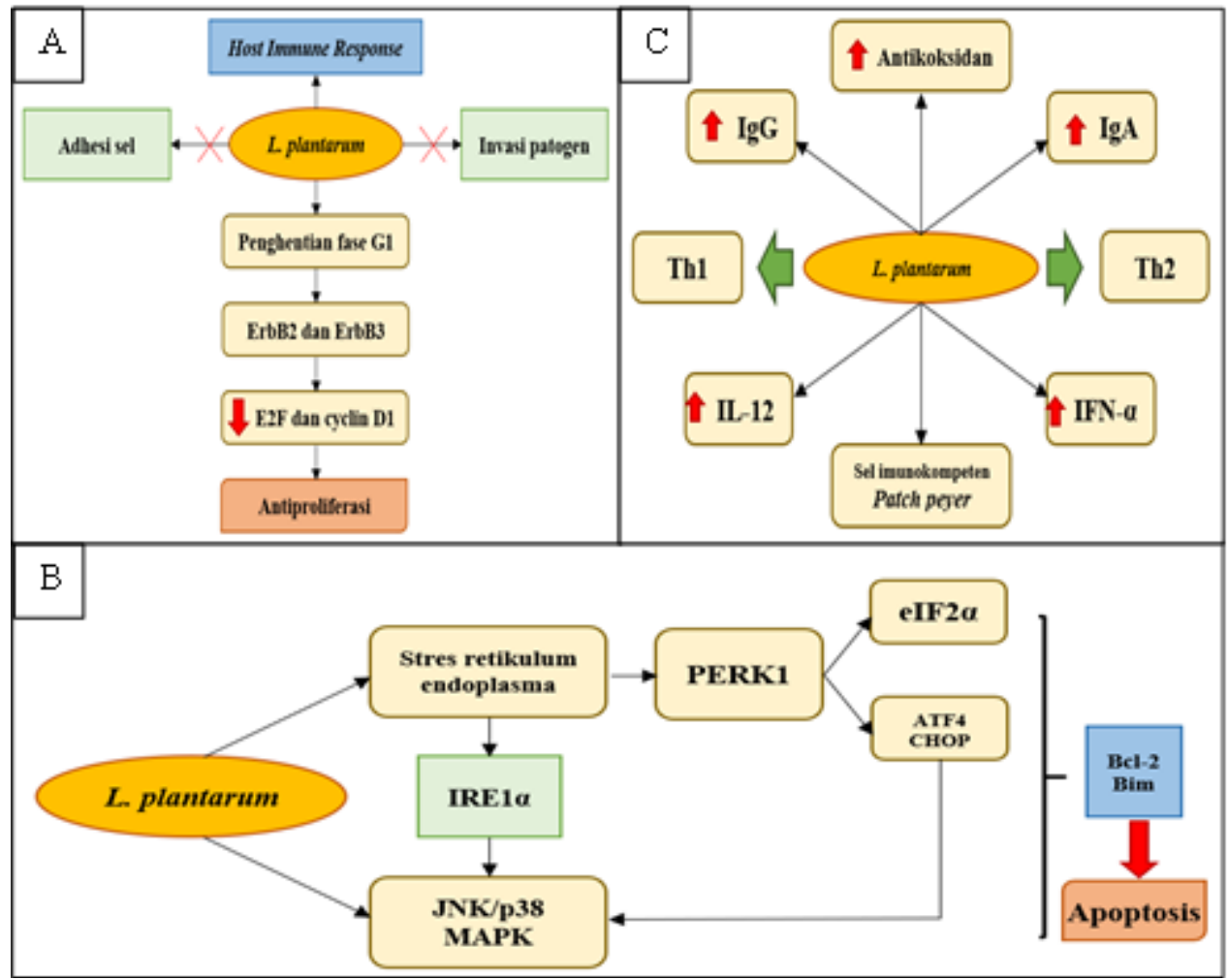

Gambar 5 Efek L. plantarum pada Kanker Kolorektal; (A) Efek Antiproliferasil; (B) Efek Apoptosis; (C) Efek Imunoterapi

L. plantarum sebagai mikrobiota usus juga dapat memodulasi farmakokinetika polifenol dan meningkatkan farmakodinamikanya dalam tubuh. Polifenol memiliki bioavailabilitas yang rendah dan mikrobiota usus dapat membantu metabolisme polifenol menjadi lebih sederhana (68). Polifenol diketahui memiliki aktivitas biologis dengan spektrum luas termasuk berefek besar pada inisiasi, promosi, dan perkembangan kanker melalui modulasi jalur pensinyalan yang berbeda (69). Senyawa ini telah digunakan untuk mencegah dan menghambat perkembangan kanker serta meningkatkan prognosis kanker (70). Mikrobiota usus seperti $L$. plantarum dan polifenol dapat menjadi kombinasi intervensi preventif kanker kolorektal.

Administrasi L. plantarum ke dalam tubuh dapat melalui beberapa mekanisme enkapsulasi. Hal ini dapat dilakukan untuk meningkatkan bioavailabilitasnya terutama saat berada pada asam lambung dengan $\mathrm{pH}$ rendah. Beberapa metode potensial sebagai enkapsulasi L. plantarum dapat dilihat pada Tabel 1.

Tabel 1 Metode Enkapsulasi Potensial L. plantarum

\begin{tabular}{|c|c|c|c|}
\hline $\begin{array}{c}\text { Metode } \\
\text { enkapsulasi }\end{array}$ & $\begin{array}{c}\text { Strain } L . \\
\text { plantarum }\end{array}$ & Hasil & Referensi \\
\hline Susu & WCFS1 & $\begin{array}{l}\text { - Viabilitas menurun drastis ketika } \\
\text { pH mencapai } 2.0\end{array}$ & $\begin{array}{l}\text { (Bove et al., } \\
\text { 2013) }\end{array}$ \\
\hline $\begin{array}{l}\text { Pasta } \\
\beta \text {-glucan }\end{array}$ & WCFS1 & $\begin{array}{l}\text { - Tidak mengalami penurunan yang } \\
\text { mencolok hingga pH } 1.5\end{array}$ & $\begin{array}{l}\text { (Bove et al., } \\
\text { 2013) }\end{array}$ \\
\hline$\beta$-glucan & NCDC 012 & $\begin{array}{l}\text { - Viabilitas menurun dari } 9.32 \text { log } \\
\text { CFU/g menjadi } 1 \text { log CFU/g setelah } \\
\text { penyimpanan } 60 \text { hari } \\
\text { Mampu bertahan hingga pH } 3.0 \\
\text { selama } 6 \text { jam (viabilitas menurun } \\
\text { dari } 9.81 \mathrm{log} \text { CFU/g menjadi } 5.39 \\
\text { log CFU/g) } \\
\text { - Viabilitas menurun dari } 6.15 \text { log }\end{array}$ & $\begin{array}{l}\text { (Shah et al., } \\
\text { 2016) }\end{array}$ \\
\hline
\end{tabular}




\begin{tabular}{|c|c|c|c|}
\hline & & $\begin{array}{l}\mathrm{CFU} / \mathrm{g} \text { menjadi } 0.99 \text { log } \mathrm{CFU} / \mathrm{g} \\
\text { ketika temperatur berubah dari } \\
55^{\circ} \mathrm{C} \text { menjadi } 75^{\circ} \mathrm{C} \text { selama } 10 \text { menit }\end{array}$ & \\
\hline $\begin{array}{l}\text { Freeze-dried } \\
\text { alginate-gum } \\
\text { arabic }\end{array}$ & ATCC 8014 & $\begin{array}{l}\text { - Viabilitas menurun setelah } 4 \text { jam } \\
\text { simulasi pH asam lambung (pH 2.5) }\end{array}$ & $\begin{array}{l}\text { (Sandoval- } \\
\text { Mosqueda et } \\
\text { al., 2019) }\end{array}$ \\
\hline $\begin{array}{l}\text { Spray-dried okana } \\
\text { oil }\end{array}$ & CIDCA 83114 & $\begin{array}{l}\text { - Tidak terjadi penurunan signifikan } \\
(>1.89 \pm 0.87 \log \mathrm{CFU} / \mathrm{g}) \text { setelah } \\
\text { penyimpanan } 90 \text { hari }\end{array}$ & $\begin{array}{l}\text { (Quintana et } \\
\text { al., 2018) }\end{array}$ \\
\hline $\begin{array}{l}\text { Spray drying chia } \\
\text { seed (Salvia } \\
\text { hispanica L.) and } \\
\text { flaxseed (Linum } \\
\text { usitatissimum L.) } \\
\begin{array}{l}\text { mucilage and } \\
\text { soluble protein }\end{array}\end{array}$ & ATCC 8014 & $\begin{array}{l}\text { - Viabilitas mencapai > } 9 \text { log } 10 \\
\text { CFU/g setelah } 45 \text { hari penyimpanan } \\
\text { dalam lemari es }\end{array}$ & $\begin{array}{l}\text { (Bustamante } \\
\text { et al., 2017) }\end{array}$ \\
\hline $\begin{array}{l}\text { Whey protein } \\
\text { isolate microgels }\end{array}$ & $\begin{array}{l}\text { Freeze dried } \\
\text { powder }\end{array}$ & $\begin{array}{l}\text { - Efek protektif tertinggi muncul } \\
\text { ketika pada pH } 4.0\end{array}$ & $\begin{array}{l}\text { (Su et al., } \\
2018)\end{array}$ \\
\hline $\begin{array}{l}\text { Dry Ca-alginate/ } \\
\text { cryoprotectant/ } \\
\text { cellulose } \\
\text { composite (ACFP) } \\
\text { capsule }\end{array}$ & CICC 6240 & $\begin{array}{l}\text { - Penurunan viabilitas pada simulasi } \\
\text { cairan usus sebesar } 2.6 \text { x } 10^{6} \\
\text { CFU/mL saat } 210 \text { menit } \\
\text { - Penurunan viabilitas sebesar } 3.3 \times \\
10^{6} \mathrm{CFU} / \mathrm{mL} \text { setelah } 160 \text { hari } \\
\text { penyimpanan pada suhu } 4^{\circ} \mathrm{C}\end{array}$ & $\begin{array}{l}\text { (Li et al., } \\
2019)\end{array}$ \\
\hline $\begin{array}{l}\text { Ekstrak } \\
\text { oligosakarida } \\
\text { Eleutherine } \\
\text { americana }\end{array}$ & TISTR 1465 & $\begin{array}{l}\text { - Viabilitas menurun dari } 9.51 \\
\text { menjadi 8.26 log CFU/g dalam } \\
\text { larutan pepton }\end{array}$ & $\begin{array}{l}\text { (Phoem et al., } \\
\text { 2019) }\end{array}$ \\
\hline $\begin{array}{l}\text { Biokomposit } \\
\text { alginat-pektin- } \\
\text { gelatin }\end{array}$ & PTCC 1058 & $\begin{array}{ll}\text { - } & \text { Terjadi penurunan viabilitas } \\
\text { sebesar } 28.52-37.7 \% \text { pada kondisi } \\
\text { simulasi gastrointestinal }\end{array}$ & $\begin{array}{l}\text { (Vaziri et al., } \\
\text { 2018) }\end{array}$ \\
\hline
\end{tabular}

\section{Kesimpulan}

Berdasarkan hasil studi literatur, L. plantarum merupakan modalitas tatalaksana kanker kolorektal yang potensial. L. plantarum menekan proliferasi melalui mekanisme penghentian fase G1 pada siklus sel dengan target reseptor ialah ErbB2 dan ErbB3. Selain itu, L. plantarum mampu menginduksi kematian sel (apoptosis) dengan mediasi Bcl-2. Bakteri ini juga berperan dalam imunoterapi dengan menstimulasi Th1 dan menghambat Th2 pada host immune system. Intervensi L. plantarum sebagai penatalaksanaan kanker kolorektal memiliki potensi yang sangat luas untuk dikembangkan dan dapat dikombinasikan dengan terapi lainnya. Akan tetapi, kajian ini memiliki keterbatasan dalam pencarian studi clinical trial terkait. Diperlukan penelitian lanjutan sehingga dapat menyempurnakan kekurangan dari kajian ini.

\section{Daftar Pustaka}

1. American Cancer Society. (2017). Colorectal Cancer Facts \& Figures 2017-2019; 1-40. Available from: https://www.cancer.org/content/dam/cancer-org/research/cancer-factsand-statistics/colorectal-cancer-facts-and-figures/colorectal-cancer-facts-and-figures2017-2019.pdf. Centers for Disease Control and Prevention. Behavioral Risk Factor Surveillance System, 2014. Public Use Data File. Colorectal Cancer Screening, 1-40. https://www.mendeley.com/viewer/?fileId=446a0f98-7242-86a5-07ffbe4c6c8cd11c\&documentId=3b9629ab-fc85-3cb8-9607-7468ed4f76a 7 
2. Hulaima, I. S., \& Carolia, N. (2016). OAINS sebagai Kemoprofilaksis Kanker Kolorektal NSAIDs as Colorectal Cancer Cemoprophylaxis. Medical Journal of Lampung University, 5, 54-58.

3. Campos, F. G. (2017). Colorectal cancer in young adults: A Difficult challenge. World Journal of Gastroenterology, 23(28), 5041-5044. https://doi.org/10.3748/wjg.v23.i28.5041

4. Globocan Observatory, W. (2019). Cancer Today - World. International Agency for Research on Cancer, 876, 2018-2019. https://gco.iarc.fr/today/data/factsheets/populations/900world-fact-sheets.pdf

5. World Health Organization. (2019). Indonesia Source GLOBOCAN 2018. International Agency for Research on Cancer, 256, 1-2. http://gco.iarc.fr/

6. Brown, K. G. M., Solomon, M. J., Mahon, K., \& O'Shannassy, S. (2019). Management of colorectal cancer. The BMJ, 366(August), 1-7. https://doi.org/10.1136/bmj.14561

7. Zils, K., Wilhelm, M., Reeh, T., \& Bielack, S. (2012). Bullous variant of acral erythema in a child after high-dose methotrexate. In Pediatric Hematology and Oncology (Vol. 29, Issue 4, pp. 378-379). https://doi.org/10.3109/08880018.2012.665982

8. Husna, T. (2018). Pengaruh Sitotoksik Ekstrak Etanol Daun Kemangi ( Ocimum sanctum ) Terhadap Sel MCF-7 dan Sel T47D. Publikasi Ilmiah, 1(18), 14-18.U. Rusli, "Inisiasi Menyusui Dini Plus Asi Ekslusif," IVEY business journal. 2012.

9. Kementerian Kesehatan Republik indonesia. (2018). Keputusan Menteri Kesehatan Republik Indonesia Nomor HK.01.07/MENKES/406/2018.

10. Deng, R., Shi, L., Zhu, W., Wang, M., Guan, X., Yang, D., \& Shen, B. (2019). Pharmacokineticsbased Dose Management of 5-Fluorouracil Clinical Research in Advanced Colorectal Cancer Treatment. Mini-Reviews in Medicinal Chemistry, 20(2), 161-167. https://doi.org/10.2174/1389557519666191011154923

11. Kahouli, I., Tomaro-Duchesneau, C., \& Prakash, S. (2013). Probiotics in colorectal cancer (CRC) with emphasis on mechanisms of action and current perspectives. Journal of Medical Microbiology, 62(PART8), 1107-1123. https://doi.org/10.1099/jmm.0.048975-0

12. Satish Kumar, R., Kanmani, P., Yuvaraj, N., Paari, K. A., Pattukumar, V., Thirunavukkarasu, C., \& Arul, V. (2012). Lactobacillus plantarum AS1 isolated from South Indian fermented food Kallappam suppress 1,2-dimethyl hydrazine (DMH)-induced colorectal cancer in male wistar rats. Applied Biochemistry and Biotechnology, 166(3), 620-631. https://doi.org/10.1007/s12010-011-9453-2

13. Zinatizadeh, N., Khalili, F., Fallah, P., Farid, M., Geravand, M., \& Yaslianifard, S. (2018). Potential preventive effect of Lactobacillus acidophilus and Lactobacillus plantarum in patients with polyps or colorectal cancer. Arquivos de Gastroenterologia, 55(4), 407-411. https://doi.org/10.1590/s0004-2803.201800000-87

14. Behera, S. S., Ray, R. C., \& Zdolec, N. (2018). Lactobacillus plantarum with Functional Properties: An Approach to Increase Safety and Shelf-Life of Fermented Foods. BioMed Research International, 2018. https://doi.org/10.1155/2018/9361614

15. Guidone, A., Zotta, T., Ross, R. P., Stanton, C., Rea, M. C., Parente, E., \& Ricciardi, A. (2014). Functional properties of Lactobacillus plantarum strains: A multivariate screening study. LWT - Food Science and Technology, 56(1), 69-76. https://doi.org/10.1016/j.lwt.2013.10.036

16. Ray, R. C., \& Didier, M. (2014). Microorganisms and Fermentation of Traditional Foods. CRC Press.

17. Ricci, A., Allende, A., Bolton, D., Chemaly, M., Davies, R., Girones, R., Koutsoumanis, K., Lindqvist, R., Nørrung, B., Robertson, L., Ru, G., Fernandez Escamez, P. S., Sanaa, M., Simmons, M., Skandamis, P., Snary, E., Speybroeck, N., Ter Kuile, B., Threlfall, J., ... Herman, L. (2017). Update of the list of QPS-recommended biological agents intentionally added to food or feed as notified to EFSA 6: suitability of taxonomic units notified to EFSA until March 2017. EFSA Journal, 15(7). https://doi.org/10.2903/j.efsa.2017.4884

18. Green, D. R., \& Llambi, F. (2015). Cell death signaling. Cold Spring Harbor Perspectives in Biology, 7(12). https://doi.org/10.1101/cshperspect.a006080 
Anak Agung Bagus Putra Indrakusuma, I Gede Krisna Arim Sadeva, Putri Ayu Wulandari, I Gede Wikania Wira Wiguna, Ni Putu Sri Indrani Remitha, I Gusti Ayu Stiti Sadvika, I Gede Putu Supadmanaba, Desak Made Wihandani: Potensi lactobacillus plantarum sebagai intervensi penatalaksanaan kanker kolorektal berbasis modifikasi mikrobiota usus. Jurnal Kesehatan. Vol 13 (2) 2020

19. Lee, H. A., Kim, H., Lee, K.-W., \& Park, K.-Y. (2016). Dead Lactobacillus plantarum Stimulates and Skews Immune Responses toward Thelper 1 and 17 Polarizations in RAW 264.7 Cells and Mouse Splenocytes. 26(0), 469-476.

20. Sharma, R., \& Tiku, A. B. (2016). Emodin inhibits splenocyte proliferation and inflammation by modulating cytokine responses in a mouse model system. Journal of Immunotoxicology, 13(1), 20-26. https://doi.org/10.3109/1547691X.2014.995243

21. Ross, S. H., \& Cantrell, D. A. (2018). Signaling and Function of Interleukin-2 in T Lymphocytes. Annual Review of Immunology, 36(1), 411-433. https://doi.org/10.1146/annurev-immunol-042617-053352

22. Mayo, B., \& Flórez, A. B. (2020). Lactic Acid Bacteria: Lactobacillus spp.: Lactobacillus plantarum. In Reference Module in Food Science. Elsevier. https://doi.org/10.1016/b978-008-100596-5.00856-8

23. Evanovich, E., De Souza Mendonça Mattos, P. J., \& Guerreiro, J. F. (2019). Comparative genomic analysis of lactobacillus plantarum: An overview. International Journal of Genomics, 2019. https://doi.org/10.1155/2019/4973214

24. Adnan, M. L. (2020). Potensi Kombinasi Bakteri Probiotik Lactobacillus reuteri dengan Sari Buah Kurma (Phoenix dactylifera) sebagai Terapi Penyakit Kanker Kolorektal. SCRIPTA SCORE Scientific Medical Journal, 1, 1-11.

25. Yamagishi, H., Kuroda, H., Imai, Y., \& Hiraishi, H. (2016). Molecular pathogenesis of sporadic colorectal cancers. Chinese Journal of Cancer, 35(1), 1-8. https://doi.org/10.1186/s40880015-0066-y

26. Murcia, O., Juárez, M., Hernández-Illán, E., Egoavil, C., Giner-Calabuig, M., Rodríguez-Soler, M., \& Jover, R. (2016). Serrated colorectal cancer: Molecular classification, prognosis, and response to chemotherapy. World Journal of Gastroenterology, 22(13), 3516-3530. https://doi.org/10.3748/wjg.v22.i13.3516

27. Kim, S. Y., \& Kim, T. Il. (2018). Serrated neoplasia pathway as an alternative route of colorectal cancer carcinogenesis. Intestinal Research, 16(3), 358. https://doi.org/10.5217/ir.2018.16.3.358

28. Erreni, M., Mantovani, A., \& Allavena, P. (2011). Tumor-associated macrophages (TAM) and inflammation in colorectal cancer. Cancer Microenvironment, 4(2), 141-154. https://doi.org/10.1007/s12307-010-0052-5

29. Renuka, \& Dahiya, D. K. (2017). The gut virome: A neglected actor in colon cancer pathogenesis. Future Microbiology, 12(15), 1345-1348. https://doi.org/10.2217/fmb-20170159

30. Shang, F. M., \& Liu, H. L. (2018). Fusobacterium nucleatum and colorectal cancer: A review. World Journal of Gastrointestinal Oncology, 10(3), 71-81. https://doi.org/10.4251/wjgo.v10.i3.71

31. Sittipo, P., Lobionda, S., Choi, K., Sari, I. N., Kwon, H. Y., \& Lee, Y. K. (2018). Toll-like receptor 2-mediated suppression of colorectal cancer pathogenesis by polysaccharide A from Bacteroides fragilis. Frontiers in Microbiology, 9(JUL), 1-11. https://doi.org/10.3389/fmicb.2018.01588

32. Ng, S. C., Wong, B. S. H. K., So, B. S. C. K., Lau, B. S. C. W., Leung, J. N. S., Tsoi, W. C., \& Lee, C. K. (2019). Streptococcus bovis bacteraemia should be investigated for early detection of colorectal pathology. Hong Kong Medical Journal, 25(5), 414. https://doi.org/10.12809/hkmj198135

33. Thakur, B. K., Malaisé, Y., \& Martin, A. (2019). Unveiling the Mutational Mechanism of the Bacterial Genotoxin Colibactin in Colorectal Cancer. Molecular Cell, 74(2), 227-229. https://doi.org/10.1016/j.molcel.2019.04.007

34. Kountouras, J., Papaefthymiou, A., Doulberis, M., \& Polyzos, S. A. (2020). Influence of Helicobacter pylori-connected metabolic syndrome on non-alcoholic fatty liver disease and its related colorectal neoplasm high risk. Liver International, 40(2), 475-476. https://doi.org/10.1111/liv.14264

35. Pleguezuelos-Manzano, C., Puschhof, J., Huber, A. R., van Hoeck, A., Wood, H. M., Nomburg, J., 
Gurjao, C., Manders, F., Dalmasso, G., Stege, P. B., Paganelli, F. L., Geurts, M. H., Beumer, J., Mizutani, T., Miao, Y., van der Linden, R., van Elst, S., Garcia, K. C., Top, J., ... Clevers, H. (2020). Mutational signature in colorectal cancer caused by genotoxic pks+ E. coli. Nature, September 2019. https://doi.org/10.1038/s41586-020-2080-8

36. Tiptiri-Kourpeti, A., Spyridopoulou, K., Santarmaki, V., Aindelis, G., Tompoulidou, E., Lamprianidou, E. E., Saxami, G., Ypsilantis, P., Lampri, E. S., Simopoulos, C., Kotsianidis, I., Galanis, A., Kourkoutas, Y., Dimitrellou, D., \& Chlichlia, K. (2016). Lactobacillus casei exerts anti-proliferative effects accompanied by apoptotic cell death and up-regulation of TRAIL in $\begin{array}{lllll}\text { colon carcinoma } & \text { cells. }\end{array}$ https://doi.org/10.1371/journal.pone.0147960

37. Saxami, G., Karapetsas, A., Lamprianidou, E., Kotsianidis, I., Chlichlia, A., Tassou, C., Zoumpourlis, V., \& Galanis, A. (2016). Two potential probiotic lactobacillus strains isolated from olive microbiota exhibit adhesion and anti-proliferative effects in cancer cell lines. Journal of Functional Foods, 24, 461-471. https://doi.org/10.1016/j.jff.2016.04.036

38. Hiraishi, N., Kanmura, S., Oda, K., Arima, S., Kumagai, K., Mawatari, S., Tanoue, S., Sasaki, F., Hashimoto, S., \& Ido, A. (2019). Extract of Lactobacillus plantarum strain 06CC2 induces JNK/p38 MAPK pathway-mediated apoptosis through endoplasmic reticulum stress in Caco2 colorectal cancer cells. Biochemistry and Biophysics Reports, 20(September). https://doi.org/10.1016/j.bbrep.2019.100691

39. Saxena, N., Katiyar, S. P., Liu, Y., Grover, A., Gao, R., Sundar, D., Kaul, S. C., \& Wadhwa, R. (2013). Molecular interactions of Bcl-2 and Bcl-xL with mortalin: Identification and functional characterization. Bioscience https://doi.org/10.1042/BSR20130034

40. Sun, M., Liu, W., Song, Y., Tuo, Y., Mu, G., \& Ma, F. (2020). The Effects of Lactobacillus plantarum-12 Crude Exopolysaccharides on the Cell Proliferation and Apoptosis of Human Colon Cancer (HT-29) Cells. Probiotics and Antimicrobial Proteins. https://doi.org/10.1007/s12602-020-09699-8

41. Ruppert, S. M., Li, W., Zhang, G., Carlson, A. L., Limaye, A., Durum, S. K., \& Khaled, A. R. (2012). The major isoforms of Bim contribute to distinct biological activities that govern the processes of autophagy and apoptosis in interleukin-7 dependent lymphocytes. Biochimica et Biophysica Acta - Molecular Cell Research, 1823(10), 1877-1893. https://doi.org/10.1016/j.bbamcr.2012.06.017

42. Chitnis, N., Pytel, D., Bobrovnikova-marjon, E., Pant, D., Maas, N., Frederick, B., Kushner, J. A., Chodosh, L. A., Koumenis, C., Fuchs, S. Y., \& Diehl, J. A. (2013). expression in a PERKdependent manner. 48(3), 353-364. https://doi.org/10.1016/j.molcel.2012.08.025.miR-211

43. Sano, R., \& Reed, J. C. (2013). ER stress-induced cell death mechanisms. Biochicm Biophys Acta, 1833(12), 1-26. https://doi.org/10.1038/jid.2014.371

44. Shenoy, A. R., Kirschnek, S., \& Häcker, G. (2014). IL-15 regulates Bcl-2 family members Bim and Mcl-1 through JAK/STAT and PI3K/AKT pathways in T cells. European Journal of Immunology, 44(8), 2500-2507. https://doi.org/10.1002/eji.201344238

45. Vega, G. G., Avilés-Salas, A., Chalapud, J. R., Martinez-Paniagua, M., Pelayo, R., Mayani, H., Hernandez-Pando, R., Martinez-Maza, O., Huerta-Yepez, S., Bonavida, B., \& Vega, M. I. (2015). P38 MAPK expression and activation predicts failure of response to CHOP in patients with Diffuse Large B-Cell Lymphoma. BMC Cancer, 15(1), 1-12. https://doi.org/10.1186/s12885015-1778-8

46. Yamamoto, N., Shoji, M., Hoshigami, H., Watanabe, K., Watanabe, K., Takatsuzu, T., Yasuda, S., Igoshi, K., \& Kinoshita, H. (2019). Antioxidant capacity of soymilk yogurt and exopolysaccharides produced by lactic acid bacteria. Bioscience of Microbiota, Food and Health, 38(3), 97-104. https://doi.org/10.12938/bmfh.18-017

47. Bosch, M., Méndez, M., Pérez, M., Farran, A., Fuentes, M. C., \& Cuñé, J. (2012). Lactobacillus plantarum CECT7315 y CECT7316 estimula la producción de inmunoglobulinas tras la vacunación contra la influenza en ancianos. Nutricion Hospitalaria, 27(2), 504-509. https://doi.org/10.3305/nh.2012.27.2.5519 
Anak Agung Bagus Putra Indrakusuma, I Gede Krisna Arim Sadeva, Putri Ayu Wulandari, I Gede Wikania Wira Wiguna, Ni Putu Sri Indrani Remitha, I Gusti Ayu Stiti Sadvika, I Gede Putu Supadmanaba, Desak Made Wihandani: Potensi lactobacillus plantarum sebagai intervensi penatalaksanaan kanker kolorektal berbasis modifikasi mikrobiota usus. Jurnal Kesehatan. Vol 13 (2) 2020

48. Lee, H. A., Kim, H., Lee, K. W., \& Park, K. Y. (2015). Dead Nano-Sized Lactobacillus plantarum Inhibits Azoxymethane/Dextran Sulfate Sodium-Induced Colon Cancer in Balb/c Mice. Journal of Medicinal Food, 18(12), 1400-1405. https://doi.org/10.1089/jmf.2015.3577

49. Biswas, S. K., Chittezhath, M., Shalova, I. N., \& Lim, J. Y. (2012). Macrophage polarization and plasticity in health and disease. Immunol. Res., 53, 11-24.

50. Mills, C. (2012). M1 and M2 Macrophages: Oracles of Health and Disease. Crit. Rev. Immunol., 32, 463-488.

51. Habil, N., Al-Murrani, W., Beal, J., \& Foey, A. D. (2011). Probiotic bacterial strains differentially modulate macrophage cytokine production in a strain-dependent and cell subset-specific manner. Benef. Microbes, 2, 283-293.

52. Christoffersen, T. E., Hult, L. T., Kuczkowska, K., Moe, K. M., Skeie, S., Lea, T., \& Kleiveland, C. R. (2014). In vitro comparison of the effects of probiotic, commensal and pathogenic strains on macrophage polarization. Probiotics Antimicrob. Proteins, 6.

53. Hradicka, P., Beal, J., Kassayova, M., \& Foey, A. (2020). A Novel Lactic Acid Bacteria Mixture : Macrophage-Targeted Prophylactic Intervention in Colorectal Cancer Management. Microorganisms, 8(3), 1-18.

54. Al Obeed, O. A., Alkhayal, K. A., Al Sheikh, A., Zubaidi, A. M., Vaali-Mohammed, M. A., Boushey, R., Mckerrow, J. H., \& Abdulla, M. H. (2014). Increased expression of tumor necrosis factor- $\alpha$ is associated with advanced colorectal cancer stages. World J. Gastroenterol, 20, 390-396.

55. Zhao, P., \& Zhang, Z. (2018). TNF- $\alpha$ promotes colon cancer cell migration and invasion by upregulating TROP-2. Oncol. Lett, 15, 3820-3827.

56. Mohania, D., Kansal, V. K., Sagwal, R., \& Shah, D. (2013). Anticarcinogenic effect of probiotic Dahi and Piroxicam on DMH-induced colorectal carcinogenesis in Wistar rats. J. Cancer Ther. Pharmacol, 1, 8-24.

57. Hirota, S. A., Ng, J., Lueng, A., Khajah, M., Parhar, K., Li, Y., Lam, V., Potentier, M. S., Ng, K., \& Bawa, M. (2011). NLRP3 inflammasome plays a key role in the regulation of intestinal homeostasis. Inflamm. Bowel Dis, 17, 1359-1372.

58. Mager, L. F., Wasmer, M. H., Rau, T. T., \& Krebs, P. (2016). Cytokine-Induced Modulation of Colorectal Cancer. Front. Oncol, 6, 96.

59. Dennis, K. L., Blatner, N. R., Gounari, F., \& Khazaie, K. (2013). Current status of interleukin-10 and regulatory T-cells in cancer. Current Opinion in Oncology, 25(6), 637-645. https://doi.org/10.1097/CCO.0000000000000006

60. Guthmiller, J. J., Graham, A. C., Zander, R. A., Pope, R. L., \& Butler, N. S. (2017). Cutting Edge: IL-10 Is Essential for the Generation of Germinal Center B Cell Responses and AntiPlasmodium Humoral Immunity . The Journal of Immunology, 198(2), 617-622. https://doi.org/10.4049/jimmunol.1601762

61. Prakoeswa, C. R. S., Herwanto, N., Prameswari, R., Astari, L., Sawitri, S., Hidayati, A. N., Indramaya, D. M., Kusumowidagdo, E. R., \& Surono, I. S. (2017). Lactobacillus plantarum IS10506 supplementation reduced SCORAD in children with atopic dermatitis. Beneficial Microbes, 8(5), 833-840. https://doi.org/10.3920/BM2017.0011

62. Ren, D., Wang, D., Liu, H., Shen, M., \& Yu, H. (2019). Two strains of probiotic Lactobacillus enhance immune response and promote naive $\mathrm{T}$ cell polarization to Th1. Food and $\begin{array}{lll}\text { Agricultural } \quad \text { Immunology, } & \text { 281-295. }\end{array}$ https://doi.org/10.1080/09540105.2019.1579785

63. Konstantinov, S. R., Kuipers, E. J., \& Peppelenbosch, M. P. (2013). Functional genomic analyses of the gut microbiota for crc screening. Nature Reviews Gastroenterology and Hepatology, 10(12), 741-745. https://doi.org/10.1038/nrgastro.2013.178

64. Cicenia, A., Scirocco, A., Carabotti, M., Pallotta, L., Marignani, M., \& Severi, C. (2014). Postbiotic activities of lactobacilli-derived factors. Journal of Clinical Gastroenterology, 48(December), S18-S22. https://doi.org/10.1097/MCG.0000000000000231

65. Hongyu Zhang, D. J. (2014). Manipulation of Microbiome, a Promising Therapy for Inflammatory Bowel Diseases. Journal of Clinical \& Cellular Immunology, 05(04). https://doi.org/10.4172/2155-9899.1000234 
66. Gosálbez, L., \& Ramón, D. (2015). Probiotics in transition: Novel strategies. Trends in Biotechnology, 33(4), 195-196. https://doi.org/10.1016/j.tibtech.2015.01.006

67. Kaur, S., \& Kaur, S. (2015). Bacteriocins as potential anticancer agents. Frontiers in Pharmacology, 6(NOV), 1-11. https://doi.org/10.3389/fphar.2015.00272

68. Tomás-Barberán, F. A., Selma, M. V., \& Espín, J. C. (2016). Interactions of gut microbiota with dietary polyphenols and consequences to human health. Current Opinion in Clinical Nutrition and Metabolic Care, 19(6), 471-476. https://doi.org/10.1097/MC0.0000000000000314

69. Alam, M. N., Almoyad, M., \& Huq, F. (2018). Polyphenols in Colorectal Cancer: Current State of Knowledge including Clinical Trials and Molecular Mechanism of Action. BioMed Research International, 2018. https://doi.org/10.1155/2018/4154185

70. Ding, S., Xu, S., Fang, J., \& Jiang, H. (2020). The Protective Effect of Polyphenols for Colorectal Cancer. Frontiers in Immunology, 11(July), 1-9. https://doi.org/10.3389/fimmu.2020.01407 